\title{
Utilization of recycled paper processing residues and clay of different sources for the production of porous anorthite ceramics
}

\author{
Mucahit Sutcu ${ }^{1}$, Sedat Akkurt* \\ Mechanical Engineering Department, Izmir Institute of Technology, 35430 Izmir, Turkey \\ Received 15 September 2009; received in revised form 15 January 2010; accepted 27 January 2010 \\ Available online 23 February 2010
}

\begin{abstract}
Production of porous anorthite ceramics from mixtures of paper processing residues and three different clays are investigated. Suitability of three different clays such as enriched clay, commercial clay and fireclay for manufacturing of anorthite based lightweight refractory bricks was studied. Porous character to the ceramic was provided by addition of paper processing residues (PPR). Samples with $30-40 \mathrm{wt} \%$ PPR fired at $1200-1400{ }^{\circ} \mathrm{C}$ contained anorthite $\left(\mathrm{CaO} \cdot \mathrm{Al}_{2} \mathrm{O}_{3} \cdot 2 \mathrm{SiO}_{2}\right)$ as major phase and some minor secondary phases such as mullite $\left(3 \mathrm{Al}_{2} \mathrm{O}_{3} \cdot 2 \mathrm{SiO}_{2}\right)$ or gehlenite $\left(2 \mathrm{CaO} \cdot \mathrm{Al}_{2} \mathrm{O}_{3} \cdot \mathrm{SiO}_{2}\right)$, depending on the calcite to clay ratio. Anorthite formation for all clay types was quite successful in samples with $30-40 \mathrm{wt} \%$ of paper residues fired at $1300^{\circ} \mathrm{C}$. A higher firing temperature of $1400{ }^{\circ} \mathrm{C}$ was needed for the fireclay added samples to produce a well sintered product with large pores. Gehlenite phase occurred mostly at lower temperatures and in samples containing higher amount of calcium (50 wt \% PPR). Compressive strength of compacted and fired pellets consisting of mainly anorthite ranged from 8 to $43 \mathrm{MPa}$.
\end{abstract}

(C) 2010 Elsevier Ltd. All rights reserved.

Keywords: Firing; Porosity; Refractories; Anorthite ceramics; Paper processing residues

\section{Introduction}

Anorthite $\left(\mathrm{CaAl}_{2} \mathrm{Si}_{2} \mathrm{O}_{8}\right)$ is one of the most important members of the plagioclase feldspar family. It is a rare constituent in magmatic and metamorphic rocks. The theoretical composition of anorthite is $20.2 \% \mathrm{CaO}, 36.6 \% \mathrm{Al}_{2} \mathrm{O}_{3}$ and $43.2 \% \mathrm{SiO}_{2}$ on a weight basis. According to $\mathrm{CaO}-\mathrm{Al}_{2} \mathrm{O}_{3}-\mathrm{SiO}_{2}$ phase diagram (Fig. 1), pure anorthite exhibits a melting point of $1553{ }^{\circ} \mathrm{C} .{ }^{1}$ Its theoretical density is $2.76 \mathrm{~g} / \mathrm{cm}^{3}$ and it has triclinic crystal structure. Anorthite is chemically most nearly related to celsian $\left(\mathrm{BaAl}_{2} \mathrm{Si}_{2} \mathrm{O}_{8}\right)$, and crystallographically most similar to albite $\left(\mathrm{NaAlSi}_{3} \mathrm{O}_{8}\right)$ and orthoclase $\left(\mathrm{KAlSi}_{3} \mathrm{O}_{8}\right)$. Its unit cell is primitive, with a $14 \AA c$-axis; the $c$-axis is twice that of albite. ${ }^{2}$ Anorthite crystals may occur as euhedral (well-formed with sharp) and tabular crystals. . $^{3,4}$

Dense anorthite ceramics are promising materials for substrate applications in electronics industry due to their

\footnotetext{
* Corresponding author. Tel.: +90 232750 6705; fax: +90 2327506701 . E-mail addresses: mucahitsutcu@iyte.edu.tr (M. Sutcu), sedatakkurt@iyte.edu.tr(S. Akkurt).

${ }^{1}$ Tel.: +90 232750 6789; fax: +90 2327506701 .
}

good physical properties such as thermal expansion coeffi-

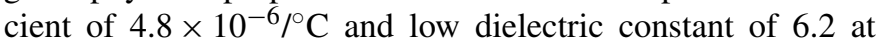
$1 \mathrm{MHz} .{ }^{5}$ Their thermal expansion coefficient is close to mullite $\left(5.3 \times 10^{-6} /{ }^{\circ} \mathrm{C}\right)$. Anorthite based glass-ceramics may also be used in a wide range of applications such as supports of catalysts for the conversion of combustion gases from engines in industrial heat exchangers for gas turbines due to their low thermal expansion coefficient, high thermal shock resistance and low dielectric constant. ${ }^{6}$ The fluorapatite-anorthite binary system can be promising in biomedicine too, as material for joint prostheses or dental roots. ${ }^{7}$ Because of these desirable properties, anorthite ceramics have attracted attention and several studies were carried out in order to decrease the firing and crystallization temperature below $1000^{\circ} \mathrm{C}^{8-10}$ For example, anorthite ceramics for substrate applications require co-firing with inexpensive conductive metals at low temperatures.

Synthesis of anorthite was extensively studied by using different methods such as sintering of mixtures of calcium carbonate, kaolinite, alumina and aluminum hydroxide in addition to mechano-chemical treatments or employing different sintering aids. ${ }^{8-12}$ Kobayashi and Kato ${ }^{8}$ have reported the fabrication of dense anorthite ceramics by sintering around $1000^{\circ} \mathrm{C}$ of kaolin and finely milled calcite mixtures. They concluded that 


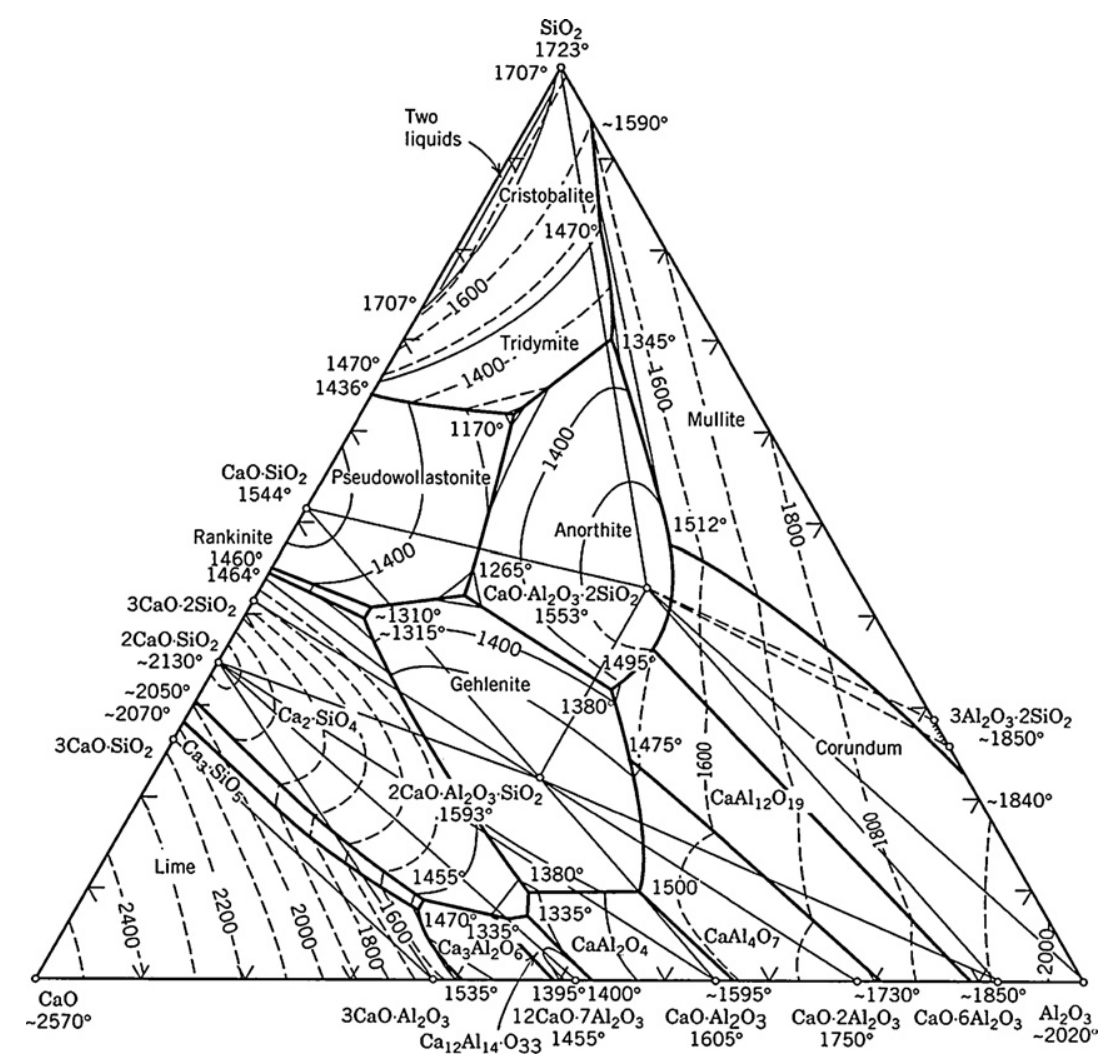

Fig. 1. $\mathrm{CaO}-\mathrm{Al}_{2} \mathrm{O}_{3}-\mathrm{SiO}_{2}$ phase diagram. ${ }^{1}$

reduction to $1.5 \mu \mathrm{m}$ of the particle size of calcite led to the production of dense anorthite ceramics with a relative density of $94 \%$ at $950{ }^{\circ} \mathrm{C}$. Mergen and Aslanoglu ${ }^{9}$ have reported that single phase anorthite ceramic with $87 \%$ theoretical density could be obtained from sintering of raw materials with coarse particles at $950{ }^{\circ} \mathrm{C}$ by using boron oxide addition. Kavalci et al. ${ }^{10}$ investigated the process variables such as temperature, soaking time, amount and type of additives and mechanochemical treatment on synthesis of anorthite ceramics. They found that anorthite formation temperature decreased down to $900^{\circ} \mathrm{C}$ by the combined effect of additive usage and intensive grinding. Okada et al. ${ }^{11}$ observed a layered $\mathrm{CaAl}_{2} \mathrm{Si}_{2} \mathrm{O}_{8}$ and anorthite formation by grinding effect in the samples fired at 900 and $1000{ }^{\circ} \mathrm{C}$, respectively. Also the effect of different sources of $\mathrm{CaO}$ such as $\mathrm{Ca}(\mathrm{OH})_{2}, \mathrm{CaCO}_{3}$, marble powder and gypsum mould waste was investigated by Kurama and Ozel ${ }^{13}$ in order to produce anorthite ceramics. They showed that anorthite could be produced as the main phase above $1200^{\circ} \mathrm{C}$ with a maximum density of $80 \%$ in samples with $\mathrm{Ca}(\mathrm{OH})_{2}$. Above mentioned studies aimed to produce dense anorthite ceramics from different sources of calcia and aluminum silicates. Recently, paper processing residues are used as a new source of raw material in the production of porous brick and porous ceramic composite consisting of the cordierite, mul-

Table 1

Experimental results of samples containing aluminum silicate and PPR (s: strong, vs: very strong for XRD peak intensity).

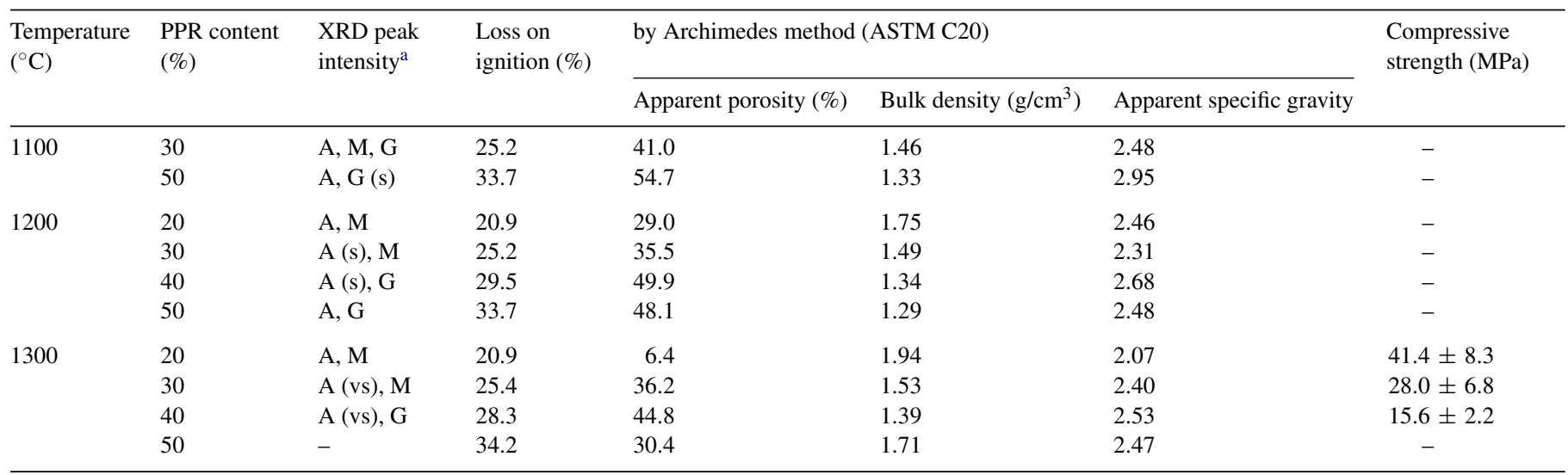

\footnotetext{
${ }^{a}$ Decreasing dominance of phases from left to right.
} 

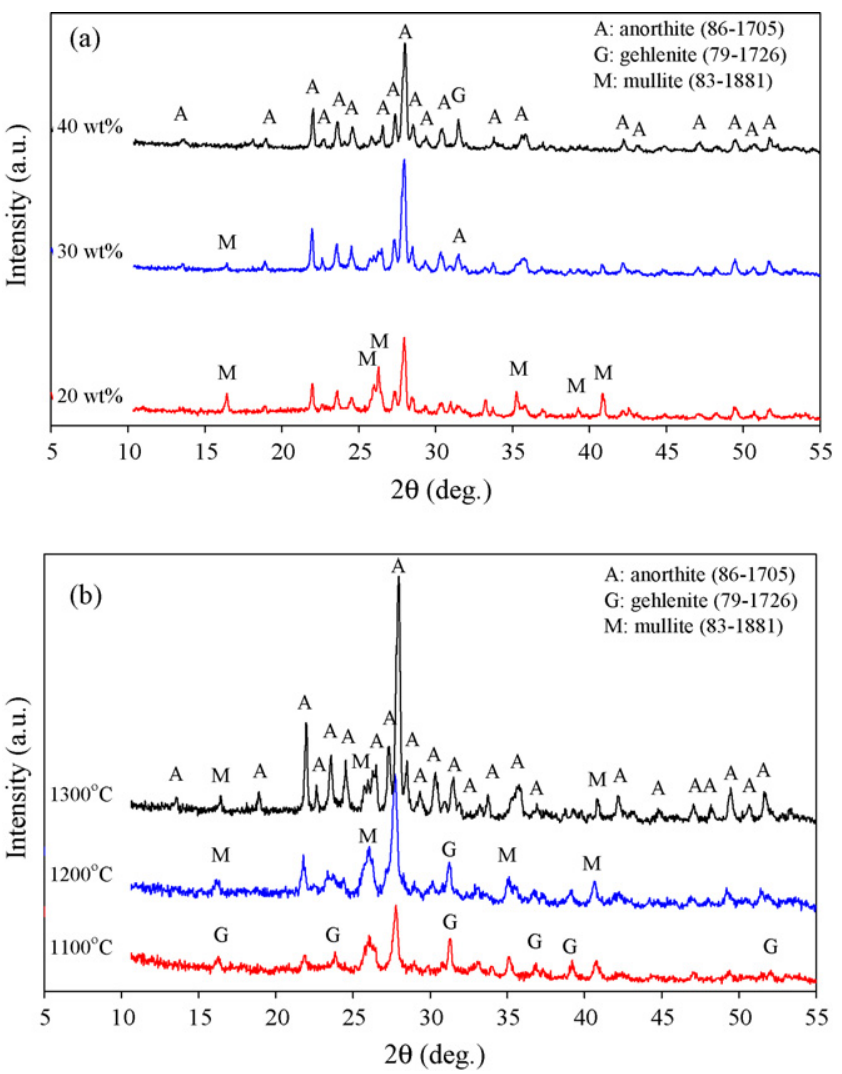

Fig. 2. XRD patterns of: (a) samples with aluminum silicate and PPR fired at $1300^{\circ} \mathrm{C}$ and (b) samples with aluminum silicate and $30 \mathrm{wt} \%$ PPR fired at different temperatures.

lite and cristobalite phases. ${ }^{14,15}$ A recent study involved open cell anorthite foams by Hojamberdiev et al. ${ }^{16}$ No study was found in the literature to target a porous anorthite structure from paper residues and from clay of different sources. In this study, porous anorthite ceramics are developed with the addition of paper processing residues as a source of calcium oxide to different clay types in order to produce lightweight insulating refractory materials. This is a preliminarily study of anorthite lightweight insulating refractory production from paper processing residues.

This study followed another study which dealt with the production of vertically perforated insulating earthenware brick for use in buildings. ${ }^{14}$ Paper processing residues composed of calcium carbonate and cellulose were used as an additive to clay raw material to make brick. In that study, different amount of paper residue additions were made to clayey material and it was found that excessive additions produced anorthite and gehlenite in the brick. So the idea of making anorthite brick with large amounts of porosity was inspired. Not only its calcium carbonate content but also its fine cellulose fibers helped in making porous anorthite based ceramics. Porous ceramics produced in this study could find applications up to $1200^{\circ} \mathrm{C}$ as refractories in backup insulation for industrial furnaces and electrical kilns for industrial and lab use. Amount of porosity in these refractories can be up to $60 \%$.
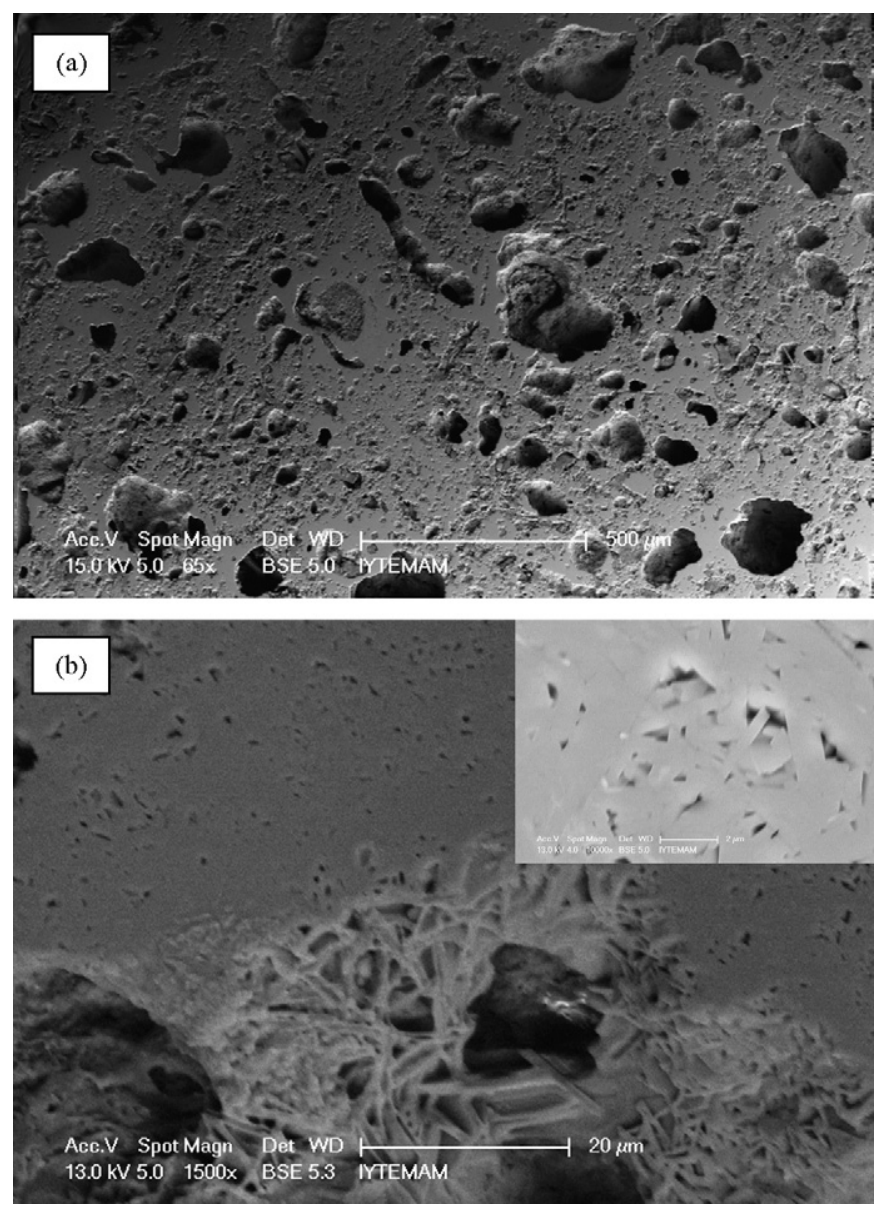

Fig. 3. Microstructures of: (a) polished and (b) thermally etched surfaces of the sample containing aluminum silicate and $30 \mathrm{wt} \%$ PPR fired at $1300^{\circ} \mathrm{C}$.

\section{Experimental procedure}

Three different clay materials were used for anorthite production such as an enriched clay material of aluminum silicate $\left(\mathrm{Al}_{2} \mathrm{Si}_{2} \mathrm{O}_{7} \cdot 2 \mathrm{H}_{2} \mathrm{O}\right.$, Alfa Aesar Co., Germany), a commercial clay (K-244, Kalemaden Co., Turkey) available in tonnage quantitites and fireclay (chamotte-125, Eczacibasi-Esan, Turkey) as alumina and silica source. Recycled paper processing residues (PPR, Levent Kagit, Turkey) that contained calcium carbonate and cellulose fibers were used as a source of calcium oxide. They were also used for pore-making due to their cellulose fiber and calcite contents. They were initially subjected to pretreatments such as drying and breaking of agglomerates in a mortar and pestle. Chemical analysis of paper residues was made by using energy dispersive X-ray fluorescence spectrometer (XRF, Spectro IQ II). The detailed phase and thermal analysis of the paper residues were given in a previous study by Sutcu and Akkurt. ${ }^{14}$

Mixtures containing different sources of clay and paper residues (between 20 and $50 \mathrm{wt} \% \mathrm{PPR}$ ) were prepared to synthesize anorthite composition $\left(\mathrm{CaO} \cdot \mathrm{Al}_{2} \mathrm{O}_{3} \cdot 2 \mathrm{SiO}_{2}\right)$. Powder mixtures were blended with ethanol in a mortar and pestle. Mixed cakes were dried in an oven at $110^{\circ} \mathrm{C}$ for $1 \mathrm{~h}$ and were powdered again before being uniaxially pressed into pellet form 
Table 2

Chemical analysis of raw materials (wt\%). PPR was analyzed by XRF while others are published chemical analysis by producers.

\begin{tabular}{lllr}
\hline Components & Commercial clay (K-244) & Fireclay (Esan-Şamot125) & PPR \\
\hline $\mathrm{SiO}_{2}$ & 59.12 & 59.00 & 6.42 \\
$\mathrm{Al}_{2} \mathrm{O}_{3}$ & 26.87 & 38.50 & 4.14 \\
$\mathrm{TiO}_{2}$ & 0.80 & 1.10 & 0.09 \\
$\mathrm{Fe}_{2} \mathrm{O}_{3}$ & 1.54 & 0.50 & 0.28 \\
$\mathrm{CaO}$ & 0.27 & 0.10 & 32.91 \\
$\mathrm{MgO}$ & 0.60 & 0.10 & 1.54 \\
$\mathrm{Na} 2$ & 0.04 & 0.05 & 0.02 \\
$\mathrm{~K}_{2} \mathrm{O}$ & 2.17 & 0.4 & 0.12 \\
$\mathrm{LOI}$ & 8.5 & 0.1 & 53.80 \\
\hline
\end{tabular}

$(\varnothing=15 \mathrm{~mm})$ in a steel die at $100 \mathrm{MPa}$. Pellets were sintered at temperatures between 1100 and $1400{ }^{\circ} \mathrm{C}$ for $1 \mathrm{~h}$ in a laboratorytype electrical kiln (Protherm, Turkey). The heating rate was $2.5^{\circ} \mathrm{C} / \mathrm{min}$ until $600^{\circ} \mathrm{C}$, and then $10^{\circ} \mathrm{C} / \mathrm{min}$ up to the dwell temperatures.

Apparent specific gravity, bulk density and apparent porosity values were measured by using boiling water absorption via Archimedes method according to ASTM C20. ${ }^{17}$ The crystalline phases of the samples were investigated by using XRD with $\mathrm{Cu} \mathrm{K} \alpha$ radiation $(\lambda=1.542 \AA)$ at $40 \mathrm{kV}$ in the $2 \theta$ intervals of $5-70^{\circ}$. Sample surfaces were polished and thermally etched at $1100{ }^{\circ} \mathrm{C}$ for $30 \mathrm{~min}$. Microstructural analysis of the polished and thermally etched surfaces was performed by using SEM and SEM-EDS (Philips XL-30SFEG and EDAX). Compressive strength tests were done on some of the samples that have the strongest anorthite composition (Shimadzu AG250kN). Cylindrical samples of $15 \mathrm{~mm}$ diameter and 22-24 mm long were uniaxially dry pressed and fired in the laboratory-type electrical kiln (Nabertherm, Germany).

\section{Results and discussion}

In this study, anorthite was produced from mixtures of paper residues and clay of different sources in order to find out if and how the type of source of aluminum silicate affects the degree of anorthite synthesis. Hence, results are presented in this section for three different types of aluminum silicate sources.

\subsection{Mixtures containing enriched clay and PPR}

Mixtures containing enriched clay labeled as aluminum silicate (Alfa Aesar) and paper processing residue (PPR) were fired at different temperatures $\left(1100-1300^{\circ} \mathrm{C}\right)$ and different PPR contents (20-50 wt\%) in order to find the optimum conditions for anorthite synthesis. The aluminum silicate used in this study was obtained from Alfa Aesar and was used as received. It was an enriched clay treated to increase fraction of clay mineral but was still found to have some quartz. Experimental results of the samples (in the cylindrical pellet form) with aluminum silicate fired at different temperatures are given in Table 1. The results obtained revealed that loss on ignition values of the samples increased gradually with an increase in the amount of the residues. Bulk densities of the fired samples decreased with increasing paper residue content up to $50 \mathrm{wt} \%$. However, samples fired at $1300{ }^{\circ} \mathrm{C}$ resulted in increased density after $40 \%$ PPR additions possibly as a result of partial vitrification and pore closure. Compressive strength of the samples fired at $1300{ }^{\circ} \mathrm{C}$ ranged from 15 to $41 \mathrm{MPa}$ depending on the amount of PPR addition.

XRD results of the samples are given in Table 1. Observed crystalline phases are labeled as $\mathrm{A}$ : anorthite $\left(\mathrm{CaO} \cdot \mathrm{Al}_{2} \mathrm{O}_{3} \cdot 2 \mathrm{SiO}_{2}\right)$, M: mullite $\left(3 \mathrm{Al}_{2} \mathrm{O}_{3} \cdot 2 \mathrm{SiO}_{2}\right)$, G: gehlenite $\left(2 \mathrm{CaO} \cdot \mathrm{Al}_{2} \mathrm{O}_{3} \cdot \mathrm{SiO}_{2}\right)$. According to XRD results, all samples contained anorthite as major phase and also minor amounts of mullite or gehlenite phases. Gehlenite occurred mostly at lower temperatures and in samples containing higher calcium (above $30 \mathrm{wt} \%$ PPR). XRD patterns of all samples fired at $1300^{\circ} \mathrm{C}$ are shown in Fig. 2a. Samples with 20, 30 and $40 \mathrm{wt} \%$ PPR clearly indicated a predominant anorthite phase. Fig. $2 \mathrm{~b}$ shows XRD patterns of the samples with $30 \mathrm{wt} \%$ paper residues fired at different temperatures. Gehlenite peaks appeared in the samples fired at 1100 and $1200{ }^{\circ} \mathrm{C}$ which completely transformed to anorthite at $1300{ }^{\circ} \mathrm{C}$. These samples also contained less amount

Table 3

Experimental results of the samples containing K-244 clay and PPR mixtures (s: strong, vs: very strong for XRD peak intensity).

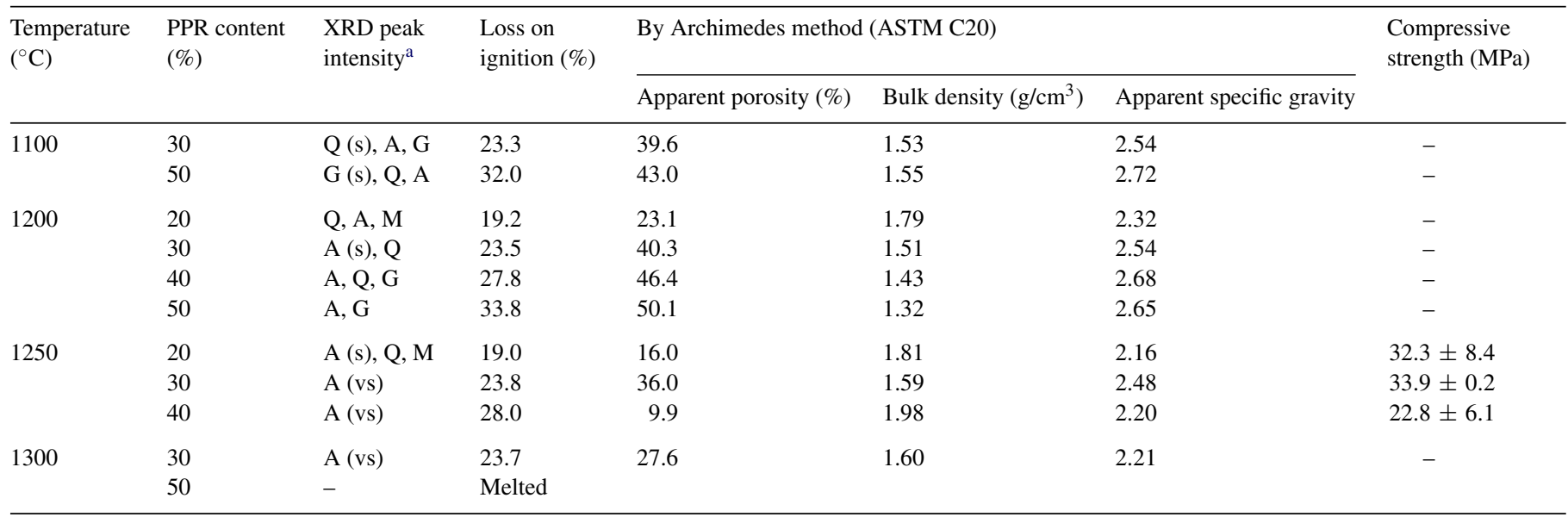

\footnotetext{
${ }^{a}$ Decreasing dominance of phases from left to right.
} 

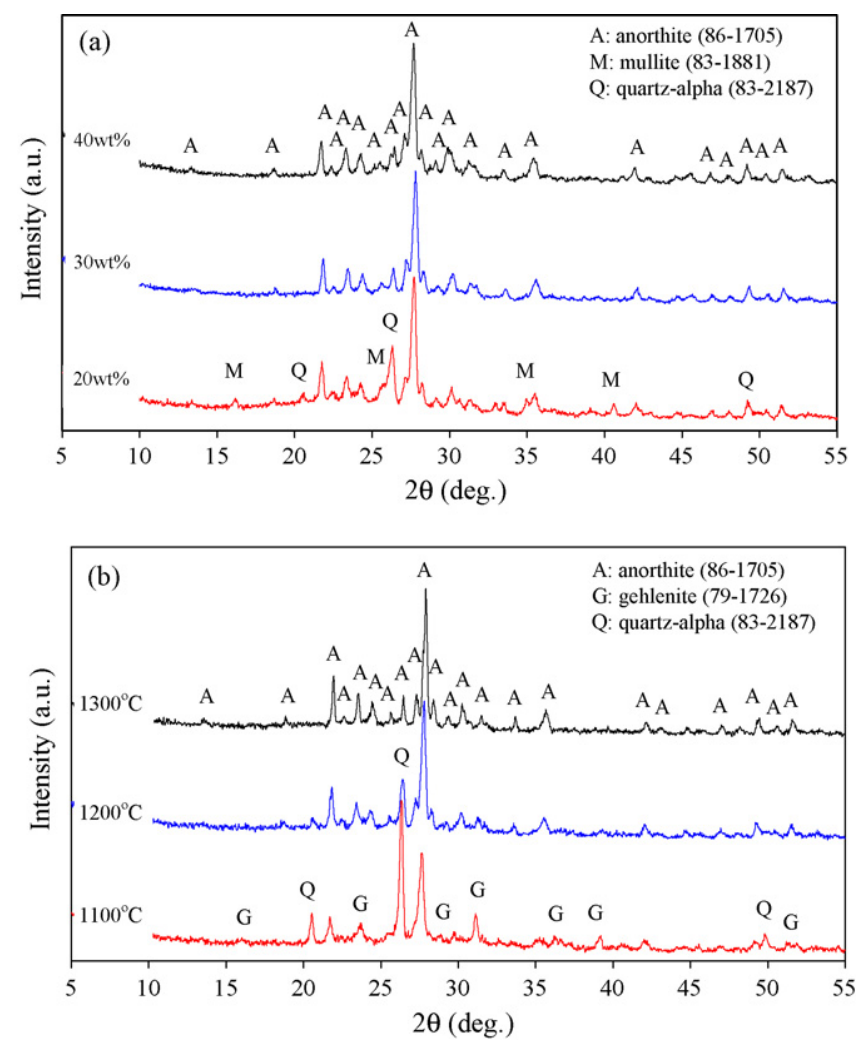

Fig. 4. XRD patterns of: (a) K-244 samples with PPR fired at $1250^{\circ} \mathrm{C}$ and (b) samples with $30 \mathrm{wt} \%$ PPR fired at different temperatures.

of mullite in addition to anorthite. The samples with $30 \mathrm{wt} \%$ PPR that contained the most intensive anorthite peak had lower bulk densities $\left(\sim 1.5 \mathrm{~g} / \mathrm{cm}^{3}\right)$.

The microstructures of samples were observed by backscattered electron image (BSE) detector of an SEM. Microstructures of polished and thermally etched surfaces of the sample containing aluminum silicate and $30 \mathrm{wt} \%$ PPR fired at $1300{ }^{\circ} \mathrm{C}$ are shown in Fig. 3a and b, respectively. As can be seen from Fig. 3a, large sized pores were present in the matrix. These pores result largely from the removal of cellulose fibers and some minor contribution from calcium carbonate decomposition during firing. These local high calcium concentrations lead to anorthite formation. ${ }^{12}$ Microstructure after thermal etching of the polished surfaces revealed that the crystalline grains are embedded in the matrix, randomly oriented. Fig. $3 b$ exhibited the presence of anorthite crystals in a well-crystallized matrix in a porous structure. These grains that had a maximum thickness of $2 \mu \mathrm{m}$ formed like an interconnected network. This network supplied strength to the structure although pores are found in the matrix. ${ }^{12}$ Well-formed crystals of anorthite of about 10 micrometers of length were clearly identified by EDS analysis.

\subsection{Mixtures containing commercial clay $(K-244)$ and $P P R$}

In this section, commercial clay (K-244, Kalemaden, Turkey) together with the paper residues were used in order to produce porous anorthite ceramic bodies. Experiments were carried out at temperatures between 1100 and $1300^{\circ} \mathrm{C}$. Paper residue con-
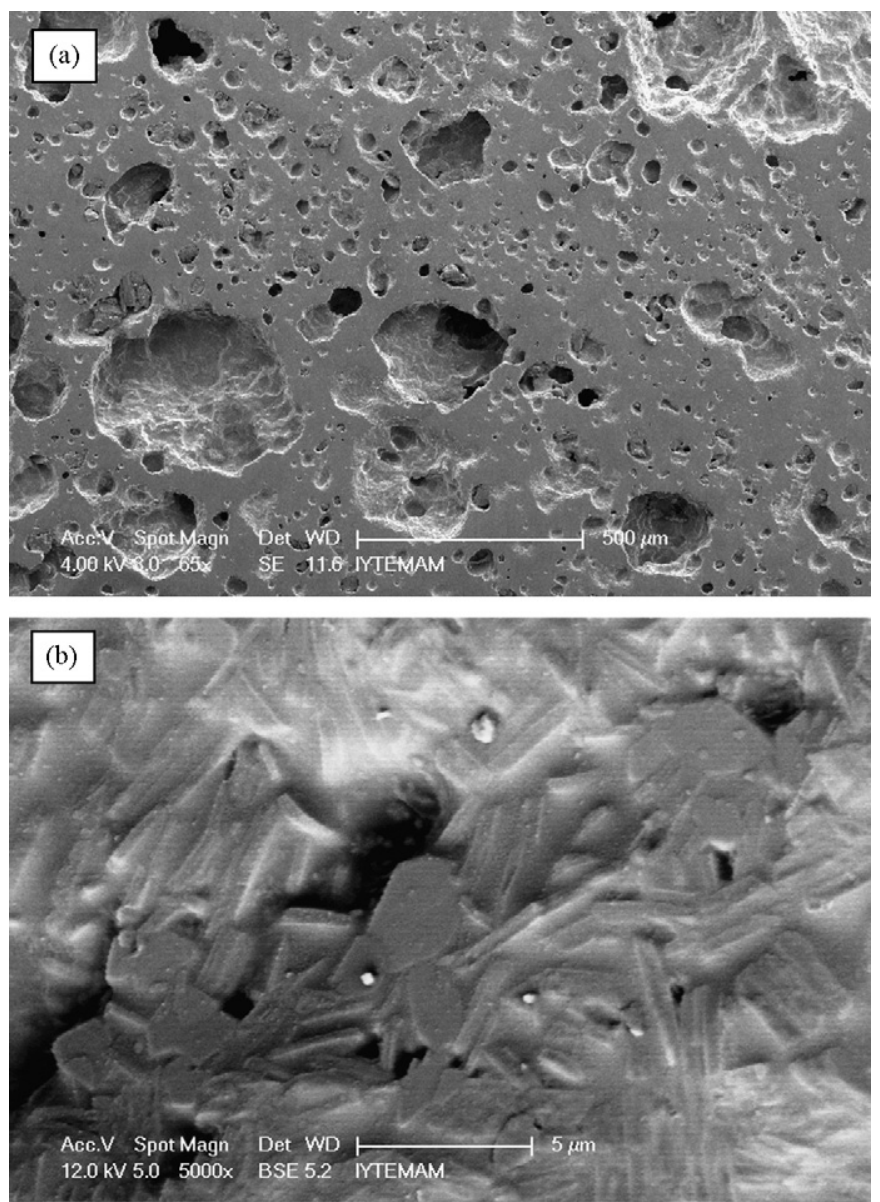

Fig. 5. SEM images of the K-244 sample with $30 \mathrm{wt} \%$ PPR fired at $1300^{\circ} \mathrm{C}$ : (a) polished surface and (b) tabular anorthite crystals embedded in glassy matrix as observed in a pore. Both samples were thermally etched at $1100^{\circ} \mathrm{C}$ for $30 \mathrm{~min}$.

tents of samples were varied from 20 to $50 \mathrm{wt} \%$ in order to find optimum conditions for formation of anorthite. Chemical composition of the clay 244 is given in Table 2 . The clay has small amount of potassium oxide which acts a fluxing agent. The clay contained mainly quartz and kaolinite with some muscovite. ${ }^{18}$

Experimental results of the samples containing K-244 and PPR mixtures fired at different temperatures are given in Table 3. The results obtained revealed that loss on ignition values of the samples increased gradually with an increase in the amount

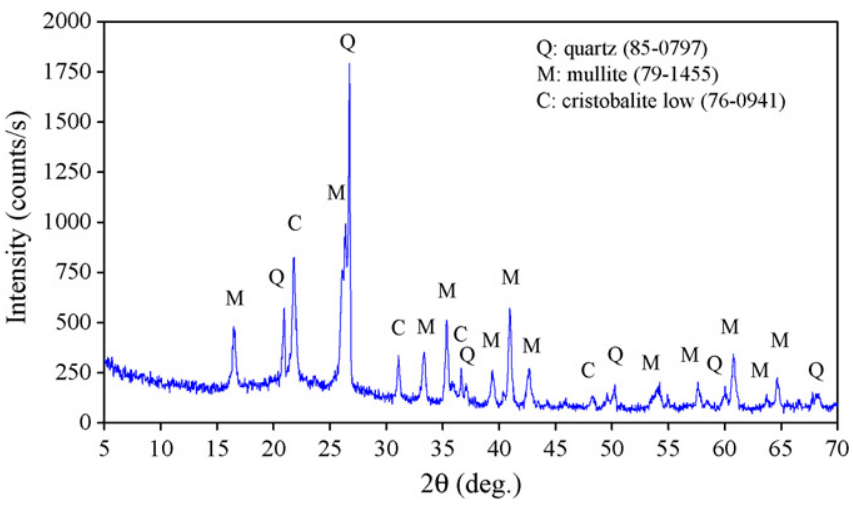

Fig. 6. XRD pattern of the fireclay (chamotte) powder. 
Table 4

Experimental results of the fireclay samples with PPR (s: strong, vs: very strong for XRD peak intensity).

\begin{tabular}{|c|c|c|c|c|c|c|c|}
\hline \multirow{2}{*}{$\begin{array}{l}\text { Temperature } \\
\left({ }^{\circ} \mathrm{C}\right)\end{array}$} & \multirow{2}{*}{$\begin{array}{l}\text { PPR content } \\
(\%)\end{array}$} & \multirow{2}{*}{$\begin{array}{l}\text { XRD peak } \\
\text { intensity }\end{array}$} & \multirow{2}{*}{$\begin{array}{l}\text { Loss on } \\
\text { ignition (\%) }\end{array}$} & \multicolumn{3}{|c|}{ By Archimedes method (ASTM C20) } & \multirow{2}{*}{$\begin{array}{l}\text { Compressive } \\
\text { strength }(\mathrm{MPa})\end{array}$} \\
\hline & & & & Apparent porosity (\%) & Bulk density $\left(\mathrm{g} / \mathrm{cm}^{3}\right)$ & Apparent specific gravity & \\
\hline \multirow{2}{*}{1200} & 30 & $\mathrm{~A}, \mathrm{M}, \mathrm{C}$ & 16.5 & 47.5 & 1.42 & 2.70 & - \\
\hline & 40 & $\mathrm{~A}, \mathrm{M}, \mathrm{G}$ & 22.1 & 51.9 & 1.33 & 2.76 & - \\
\hline 1400 & 20 & $\mathrm{M}(\mathrm{s}), \mathrm{A}$ & 11.0 & 0.1 & 2.02 & 2.02 & $42.3 \pm 1.7$ \\
\hline
\end{tabular}

${ }^{\text {a }}$ Decreasing dominance of phases from left to right.

of the residues. Their bulk densities generally decreased with increasing PPR content. Some increase in the densities of the samples with 30-50 wt\% PPR was observed probably due to vitrification at 1250 and $1300{ }^{\circ} \mathrm{C}$. In fact, the samples with $50 \mathrm{wt} \%$ PPR melted at $1300{ }^{\circ} \mathrm{C}$. Apparent porosities of the samples began to decrease with increasing temperatures from $1200^{\circ} \mathrm{C}$. The densities of anorthite based samples (with 30-40 wt\% PPR) varied from 1.51 to $1.98 \mathrm{~g} / \mathrm{cm}^{3}$. Compressive strength of the samples fired at $1250^{\circ} \mathrm{C}$ ranged from 22 to $33 \mathrm{MPa}$ depending on the amount of PPR addition.

XRD results of the samples are given in Table 3. Observed crystalline phases are labeled as $\mathrm{A}$ : anorthite $\left(\mathrm{CaO} \cdot \mathrm{Al}_{2} \mathrm{O}_{3}\right.$. $\left.2 \mathrm{SiO}_{2}\right)$, Q: quartz $\left(\mathrm{SiO}_{2}\right), \mathrm{M}$ : mullite $\left(3 \mathrm{Al}_{2} \mathrm{O}_{3} \cdot 2 \mathrm{SiO}_{2}\right), \mathrm{G}$ : gehlenite $\left(2 \mathrm{CaO} \cdot \mathrm{Al}_{2} \mathrm{O}_{3} \cdot \mathrm{SiO}_{2}\right)$. Samples containing 30 and
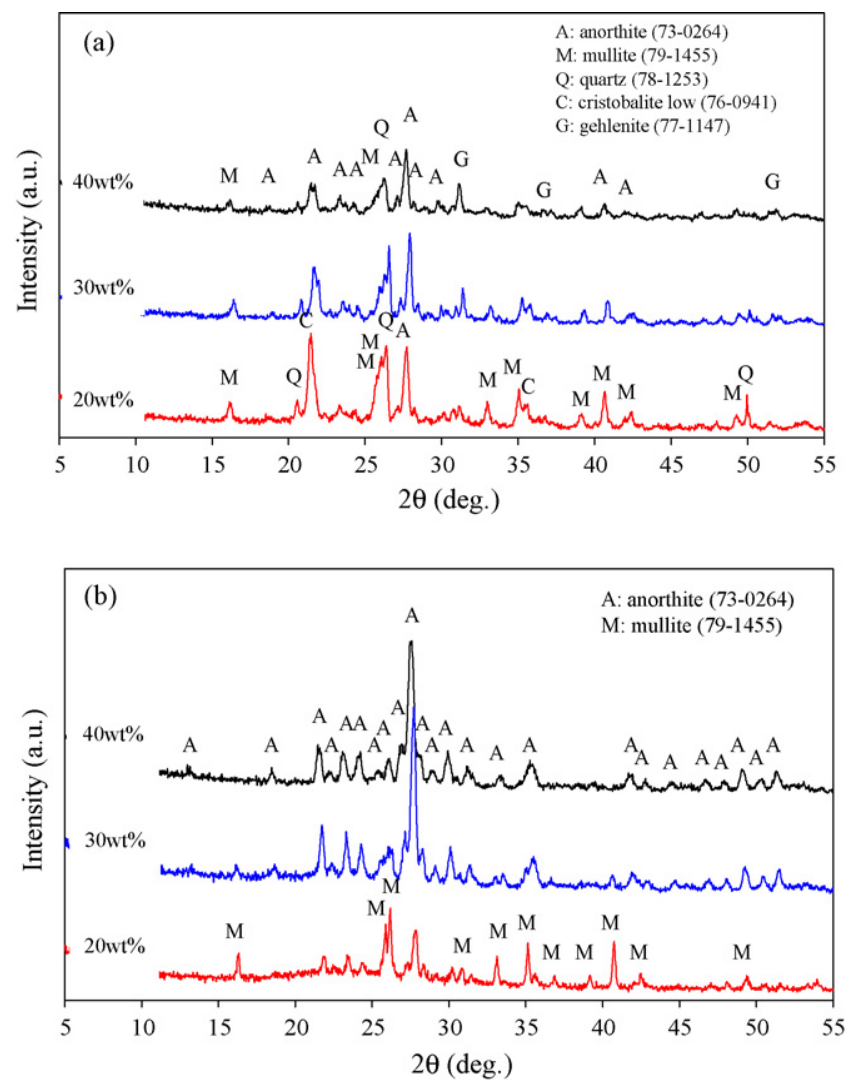

Fig. 7. XRD patterns of the samples containing fireclay: (a) $1200^{\circ} \mathrm{C}$ and (b) $1400^{\circ} \mathrm{C}$.
$40 \mathrm{wt} \%$ PPR contained major anorthite phases at 1250 and $1300{ }^{\circ} \mathrm{C}$ of firing temperatures. When the firing temperature increased, anorthite and gehlenite formation became more stable. As expected, gehlenite occurred mostly in the sample containing $50 \mathrm{wt} \%$ PPR. XRD patterns of all samples fired at $1250{ }^{\circ} \mathrm{C}$ are shown in Fig. 4a. XRD results of the samples with 20, 30 and $40 \mathrm{wt} \%$ PPR indicated strong anorthite formation at $1250^{\circ} \mathrm{C}$. Fig. $4 \mathrm{~b}$ shows XRD patterns of the samples with $30 \mathrm{wt} \%$ PPR fired at different temperatures. Minor phases such as quartz and gehlenite appeared in the samples fired at 1100
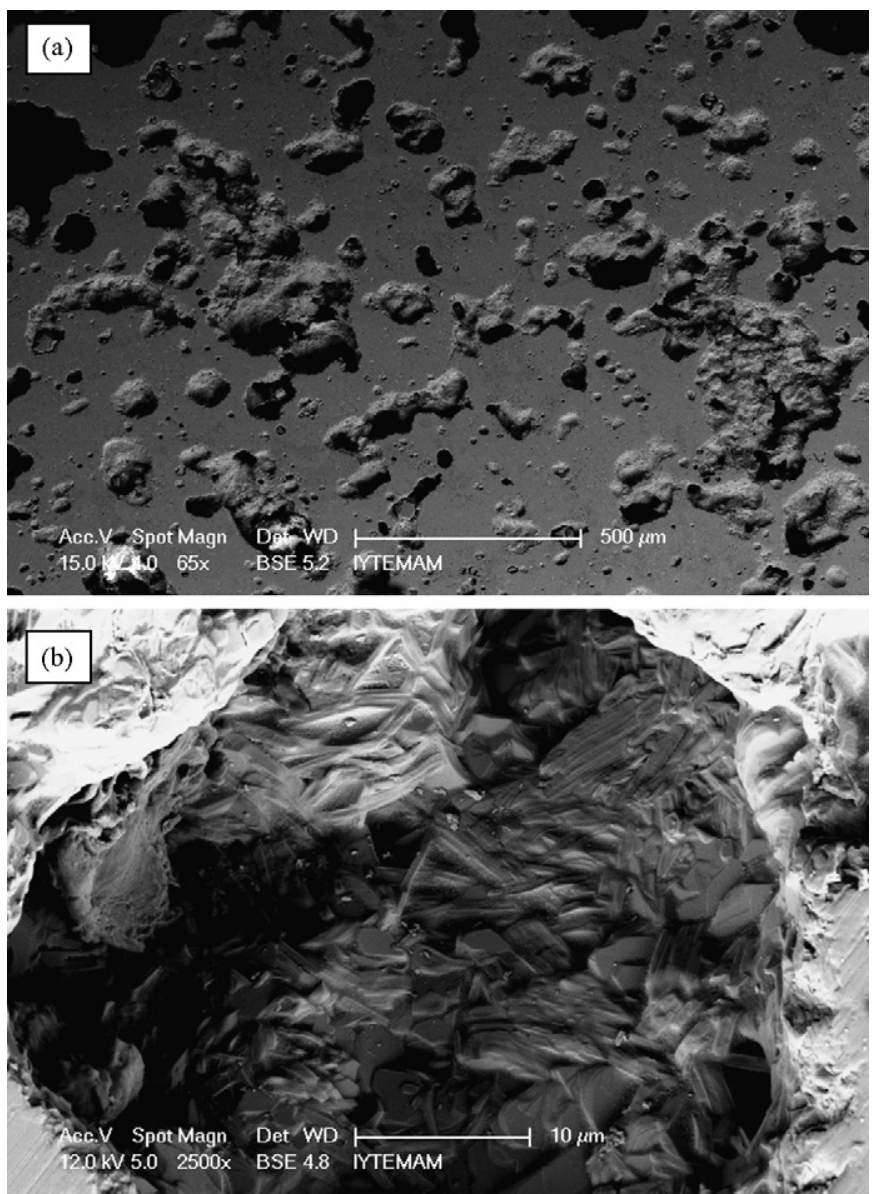

Fig. 8. SEM images of the fireclay sample with $30 \mathrm{wt} \%$ PPR fired at $1400^{\circ} \mathrm{C}$ : (a) thermal etched polished cross-sectional surface and (b) tabular crystals in pores. 

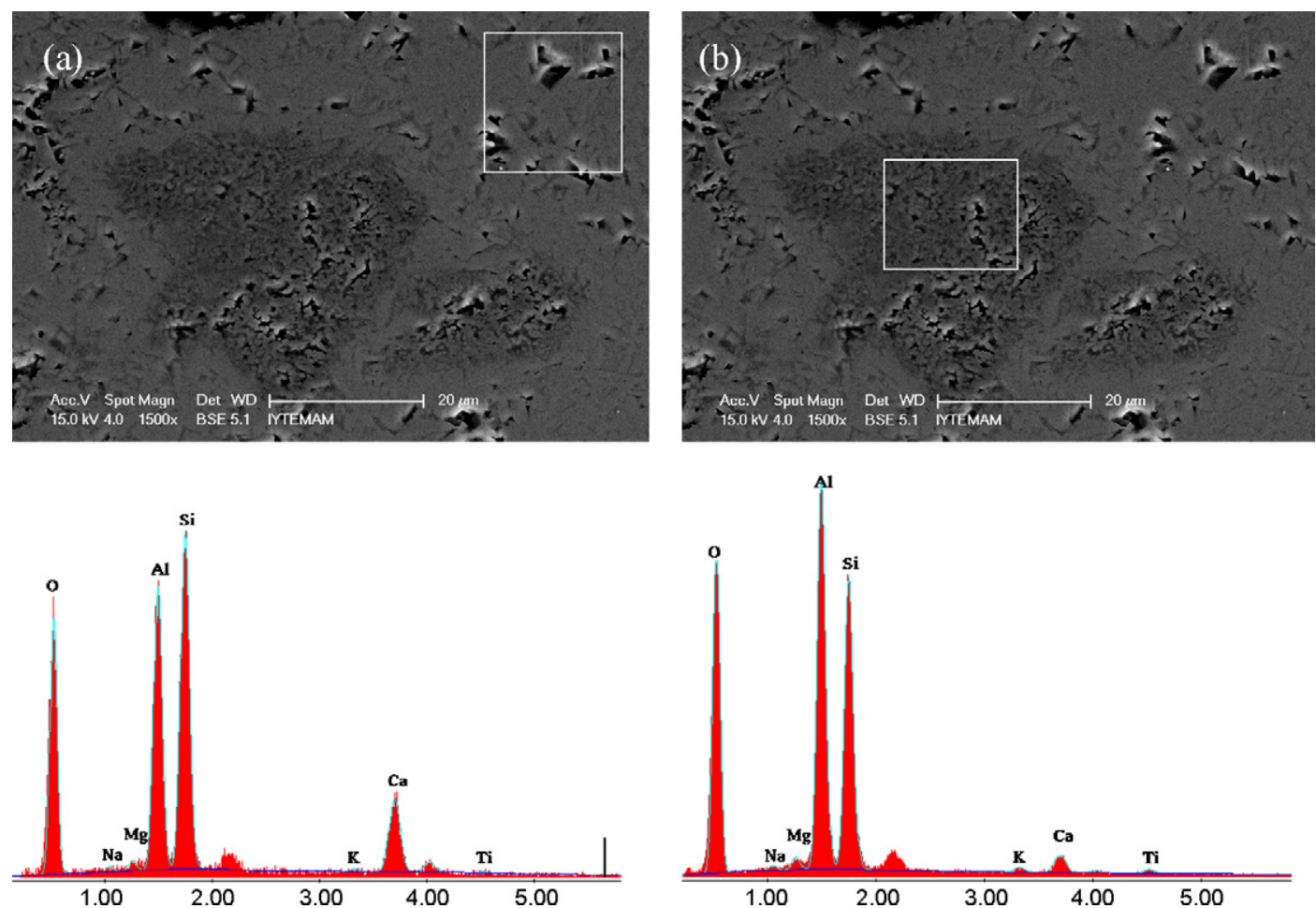

Fig. 9. SEM-EDS results of the fireclay sample with $30 \mathrm{wt} \%$ PPR fired at $1400^{\circ} \mathrm{C}$ : (a) light gray region and (b) dark gray region.

and $1200{ }^{\circ} \mathrm{C}$ that were completely transformed to anorthite at $1300{ }^{\circ} \mathrm{C}$.

SEM images of polished and thermally etched surfaces of $\mathrm{K}-244$ samples with $30 \mathrm{wt} \% \mathrm{PPR}$ fired at $1300{ }^{\circ} \mathrm{C}$ are shown in Fig. 5a and b, respectively. As can be seen from Fig. 5a, pores of varying sizes $(5-500 \mu \mathrm{m})$ were observed in the ceramic. Pores formed most probably due to the removal of fine cellulose fibers in addition to decomposition of calcium carbonate during firing. Potassium oxide $\left(\mathrm{K}_{2} \mathrm{O}\right)$ in the clay acts as a fluxing agent, therefore the fired body was easily vitrified at high temperatures. Fluxing agents cause a reduction in refractoriness properties of the samples. Therefore, this type clay may be unfavorable for production of insulating firebrick. Randomly oriented tabular and layered crystals with different geometric shapes appeared in the pores as shown in Fig. 5b. They were identified from their crystal geometries based on literature. ${ }^{4}$ SEM-EDS analysis of the sample with $30 \mathrm{wt} \%$ PPR indicated that the tabular crystals in Fig 5b were anorthite with the following composition: Si (23.5 wt\%), Al (18.4 wt \%), Ca (16.5 wt \%) and also fluxing elements such as $\mathrm{Mg}(1.1 \mathrm{wt} \%)$, Fe $(0.9 \mathrm{wt} \%)$ and $\mathrm{K}(0.8 \mathrm{wt} \%)$.

\subsection{Mixtures containing fireclay (chamotte) and PPR}

Experience with commercial clay 244 in the previous section indicated that alkalis along with other impurities were mainly responsible for premature vitrification at lower than expected temperatures. Therefore a decision was made to use a fireclay powder (chamotte) to increase refractoriness of the synthesized anorthite by reducing glassy material in the structure. In this section, ground fireclay (chamotte-125, obtained from Eczacıbaşı
Esan, Turkey) was used as clay raw material for high refractoriness of the products. $75 \%$ of its particle size was below $45 \mu \mathrm{m}$. Its loss on ignition value was almost zero. Its chemical composition consisted of a high percentage of silica and alumina, and a low percentage of the oxides of sodium, potassium and calcium (Table 2). Mineral composition of the fireclay was found to consist of quartz, mullite and cristobalite (Fig. 6). Since it is fired at a high temperature, kaolin mineral was transformed to mullite and glass, besides a part of quartz was transformed to cristobalite.

In this study, 20, 30 and $40 \mathrm{wt} \%$ PPR were added to fireclay in order to synthesize anorthite. Samples were fired at 1200 and $1400{ }^{\circ} \mathrm{C}$ due to their higher refractoriness. Experimental

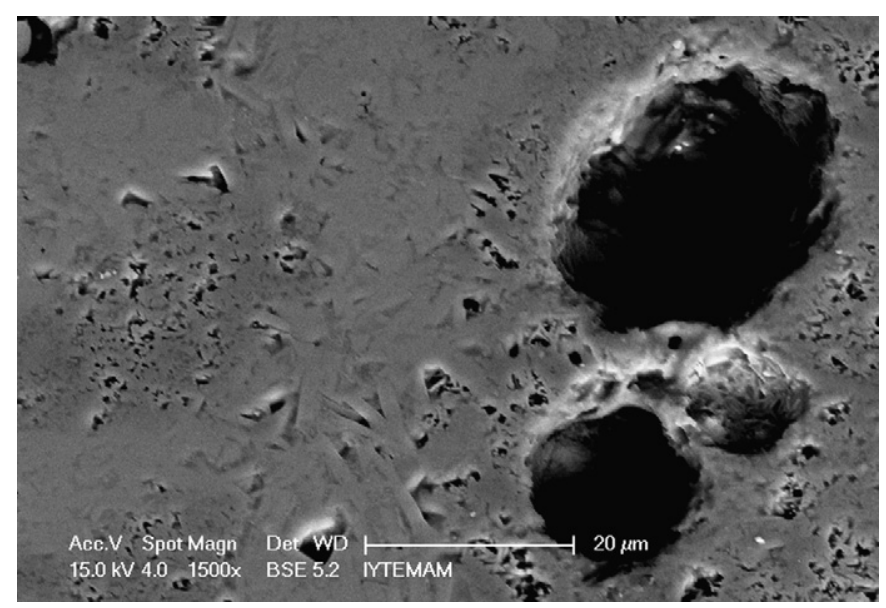

Fig. 10. SEM image of polished, thermally etched surface of the fireclay sample with $30 \mathrm{wt} \% \mathrm{PPR}$ fired at $1400{ }^{\circ} \mathrm{C}$. 

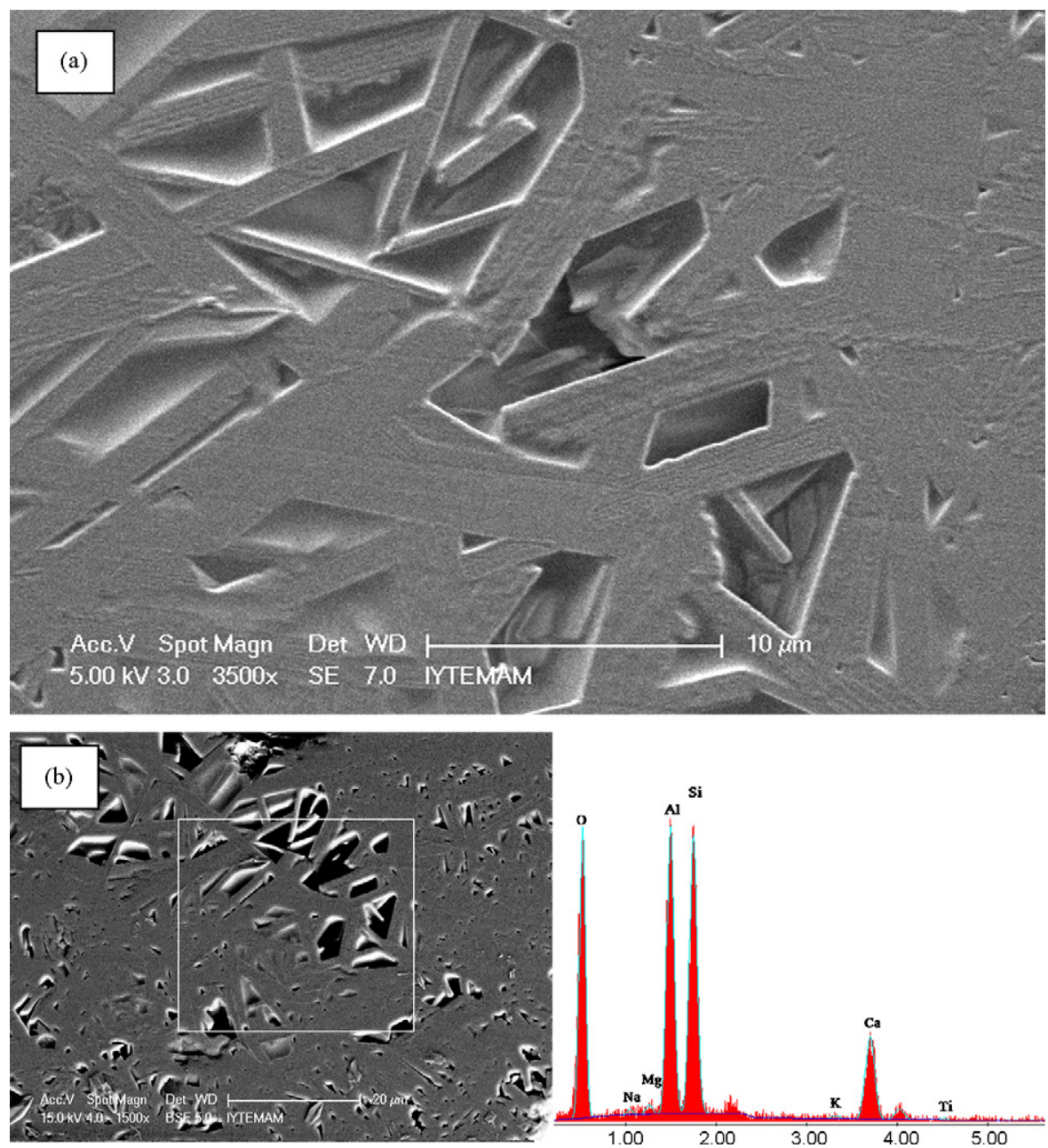

Fig. 11. (a) Tabular anorthite crystals and (b) SEM-EDS result of the sample with $40 \mathrm{wt} \%$ PPR sintered at $1400^{\circ} \mathrm{C}$.

results of the fireclay samples are given in Table 4 . All of the samples that were fired at $1200^{\circ} \mathrm{C}$, and the sample with $30 \mathrm{wt} \%$ PPR fired at $1400^{\circ} \mathrm{C}$ showed dimensional stability. Whereas, the samples with 20 and $40 \mathrm{wt} \%$ PPR sintered at $1400^{\circ} \mathrm{C}$ linearly shrank and expanded by around $6 \%$ and $7 \%$, respectively. Bulk densities of samples with 20 and $30 \mathrm{wt} \%$ PPR increased with increasing temperature. Interestingly, sample with $40 \mathrm{wt} \%$ PPR was observed to have decreased bulk density with increasing firing temperature. Compressive strength of the samples fired at $1400{ }^{\circ} \mathrm{C}$ ranged from 8 to $43 \mathrm{MPa}$ depending on the amount of PPR addition.

XRD patterns of the samples fired at 1200 and $1400^{\circ} \mathrm{C}$ are shown in Fig. 7a and b, respectively. In the samples fired at $1200{ }^{\circ} \mathrm{C}$, the secondary phases such as gehlenite, mullite, cristobalite and quartz as well as anorthite were observed. However, the degree of crystallinity of anorthite increased with increasing firing temperature (Fig. 7b). In the samples with 30 and $40 \mathrm{wt} \%$ additives, the secondary phases were transformed to anorthite as major phase with increasing temperature. Stoichiometric anorthite composition was apparently satisfied in the samples with 30 and $40 \%$ PPR by weight at $1400{ }^{\circ} \mathrm{C}$. In addition, less amount of mullite was observed in the sample with $30 \mathrm{wt} \%$ PPR as there was enough calcium to produce anorthite.
Microstructures of the samples having anorthite composition were investigated. As can be seen from SEM image of the sample with $30 \mathrm{wt} \%$ PPR sintered at $1400^{\circ} \mathrm{C}$ in Fig. 8a, large sized pores occurred in the body due to removal of fine cellulose fibers and calcium carbonate decomposition during firing. Because BSE (back-scattered electron imaging mode) was used in imaging, brightness differences such as dark gray and lighter gray were observed in some regions of the specimen cross-sectional surface (Fig. 9). Randomly oriented tabular or plate-like crystals were observed in pores (Fig. 8b), which are most possibly anorthite crystals. In Fig. 9, SEM-EDS results of the sample with $30 \mathrm{wt} \% \mathrm{PPR}$ sintered at $1400^{\circ} \mathrm{C}$ indicated that light gray regions (Fig. 9a) were anorthite and dark gray regions (Fig. 9b) were mullite. While anorthite regions contained $28.9 \mathrm{wt} \% \mathrm{Si}, 19.6 \mathrm{wt} \% \mathrm{Al}$ and $12.4 \mathrm{wt} \% \mathrm{Ca}$ elements, mullite regions contained $27.6 \mathrm{wt} \% \mathrm{Al}$ and $27.3 \mathrm{wt} \% \mathrm{Si}$. Since $\mathrm{Si}$ amount in both regions were partly higher, vitrification was observed. While mullite-rich regions have fine grained structure, anorthite-rich regions had coarse grained structure (Fig. 10). SEM imaging after thermal etching of the polished surfaces revealed that the crystalline structures were embedded into the glassy matrix and were randomly oriented. Dimensions of anorthite grains were around $3 \mu \mathrm{m} \times 10 \mu \mathrm{m}$. Clusters of mullite 
grains were distributed throughout the polished cross-section of sample with $30 \%$ PPR. Fig. 11a shows the microstructure of thermally etched surface of the sample with $40 \mathrm{wt} \%$ PPR sintered at $1400{ }^{\circ} \mathrm{C}$. Lengths of anorthite crystals (around $20 \mu \mathrm{m}$ ) were partially bigger in this sample with $40 \%$ PPR than that of samples with $30 \mathrm{wt} \%$ PPR. As can be observed from XRD results, this sample with $40 \%$ PPR included completely anorthite. Mullite was not observed. This was confirmed by SEM-EDS analysis (Fig. 11b). According to the area that was analyzed, composition was an anorthite composition $(23.4 \mathrm{wt} \% \mathrm{Si}, 19.7 \mathrm{wt} \%$ $\mathrm{Al}, 13.7 \mathrm{wt} \% \mathrm{Ca})$. This result was almost similar with that of a commercial insulating firebrick (K-23 type IFB). ${ }^{19}$

Compressive strength measurements of the samples showed a large scatter due to a number of factors. Laminations may have occurred during dry pressing of the compacts. Different temperatures were used for firing these samples to obtain full anorthite composition, which may produce different state of densification, vitrification in samples. The sample with K-244 (Table 3) especially was partially vitrified after thermal treatment at $1250{ }^{\circ} \mathrm{C}$ and was fully vitrified and deformed at $1300{ }^{\circ} \mathrm{C}$. The large $\mathrm{K}_{2} \mathrm{O}$ content of this sample is a further factor to effect degree of vitrification and the mechanical behavior.

\section{Conclusions}

Production of porous anorthite ceramics from the mixtures of PPR with three different types of clays was successfully achieved. Suitability of three different clays such as aluminum silicate, clay with alkalis and fireclay in the manufacturing of anorthite based lightweight insulating firebricks was determined. All samples of mixtures with 30-40 wt \% PPR fired at $1200-1400{ }^{\circ} \mathrm{C}$ contained anorthite as major phase and also minor secondary phases such as mullite or gehlenite phases in some mixtures. Laboratory grade enriched clay, when mixed with PPR, was able to produce anorthite at $1300^{\circ} \mathrm{C}$ in a porous ceramic form. Use of a commercial clay that is available in tonnage quantities, produced anorthite at lower temperatures but with higher bulk densities. In these samples $1300^{\circ} \mathrm{C}$ was too high to produce a ceramic because of premature melting during firing. This was attributed to the presence of alkalis in the clay that fluxed the mixtures. Finally, a higher firing temperature of $1400{ }^{\circ} \mathrm{C}$ was needed for the fireclay samples to produce anorthite in a porous ceramic form. Gehlenite phase formed mostly at lower temperatures and in samples containing higher calcium content (50 wt\% PPR). Compressive strengths of the samples ranged from 8 to $43 \mathrm{MPa}$. Upon completion of this study porous thermally insulating anorthite ceramics were successfully produced. More work needs to be done to further advance this study to produce larger and more porous ceramic pieces for thermal conductivity tests.

\section{Acknowledgements}

The authors would like to thank the staff of the Center for Materials Research for their helps in SEM and XRD analysis.

\section{References}

1. Levin EM, Robbins CR, McMurdie HF. Phase diagrams for ceramists. Columbus, OH: The American Ceramic Society; 1975.

2. Kempster CJE, Megaw HD, Radoslovich EW. The structure of anorthite, $\mathrm{CaAl}_{2} \mathrm{Si}_{2} \mathrm{O}_{8}$. I. Structure analysis. Acta Crystallogr 1962;15: 1005-17.

3. www.handbookofminerology.org/pdfs/anorthite.pdf.

4. Palace C. The minerals of Franklin and Sterling Hill, Sussex County, New Jersey, U.S. Geological Survey Professional Paper 180; 1935.

5. Gdula RA. Anorthite ceramic dielectrics. Am Ceram Soc Bull 1971;50:555-7.

6. Boudchicha MR, Achour S, Harabi A. Crystallization and sintering of cordierite and anorthite based binary ceramics. J Mater Sci Lett 2001;20:215-7.

7. Agathopoulos S, Tulyaganov DU, Marques PAAP, Ferro MC, Fernandes MHV, Correia RN. The fluorapatite-anorthite system in biomedicine. Biomaterials 2003;24:1317-31.

8. Kobayashi Y, Kato E. Low-temperature fabrication of anorthite ceramics. J Am Ceram Soc 1994;77(3):833-4.

9. Mergen A, Aslanoglu Z. Low-temperature fabrication of anorthite ceramics from kaolinite and calcium carbonate with boron oxide addition. Ceram Int 2003;29:667-70.

10. Kavalci S, Yalamaç E, Akkurt S. Effects of boron addition and intensive grinding on synthesis of anorthite ceramics. Ceram Int 2008;34: 1629-35.

11. Okada K, Watanabe N, Jha KV, Kameshima Y, Yasumori A, MacKenzie KJD. Effects of grinding and firing conditions on $\mathrm{CaAl}_{2} \mathrm{Si}_{2} \mathrm{O}_{8}$ phase formation by solid-state reaction of kaolinite with $\mathrm{CaCO}_{3}$. Appl Clay Sci 2003;23:329-36.

12. Traoré K, Kabré TS, Blanchart P. Gehlenite and anorthite crystallisation from kaolinite and calcite mix. Ceram Int 2003;29:377-83.

13. Kurama S, Ozel E. The influence of different $\mathrm{CaO}$ source in the production of anorthite ceramics. Ceram Int 2009;35:827-30.

14. Sutcu M, Akkurt S. The use of recycled paper processing residues in making porous brick with reduced thermal conductivity. Ceram Int 2009;35:2625-31.

15. Dasgupta S, Das SK. Paper pulp waste-a new source of raw material for the synthesis of a porous ceramic composite. Bull Mater Sci 2002;25(October (5)):381-5.

16. Hojamberdiev M, Torrey JD, Beltrã MS, Wondraczek L. Cellular anorthite glass-ceramics: synthesis, microstructure and properties. J Am Ceram Soc 2009;92(11):2598-604.

17. Annual book of ASTM standards, vol. 15.01, ASTM Standards C20. Test methods for apparent porosity, water absorption, apparent specific gravity, and bulk density of burned refractory brick and shapes by boiling water.

18. Budak M, Sütçü M, Akkurt S, Böke H. Investigation of the properties of commercial clays for potential use in preparation of Horasan mortar for conservative purposes. In: Yapar S, editor. Proceedings of XI national clay symposium. 2003. p. 381-9 (in Turkish).

19. Brosnan DA. Alumina-silica brick. In: Schacht CA, editor. Refractories handbook. New York: Marcel Dekker Inc.; 2004. p. 79-107. 